\title{
Cytotoxic and apoptotic potential of Myristica fragrans Houtt. (mace) extract on human oral epidermal carcinoma KB cell lines
}

\author{
Gayathri Rengasamy ${ }^{1,3}$, Anuradha Venkataraman², Vishnu Priya Veeraraghavan ${ }^{3}$, Mallika Jainu ${ }^{4 *}$ \\ ${ }^{1}$ Department Of Biochemistry, Research and Development Centre, Bharathiyar University, Coimbatore-641106, Tamil Nadu, \\ India, ${ }^{2}$ Department of Biochemistry, Mohammed Sathak College of Arts and Science, Sholinganallur, Chennai-600119, Tamil \\ Nadu, India, ${ }^{3}$ Department of Biochemistry, Saveetha Dental College and Hospital, Saveetha University, Velappanchavadi, \\ Chennai-600 077, Tamil Nadu, India, ${ }^{4}$ Department of Biochemistry, Biogen Care Research Centre, Chennai-600014, \\ Tamil Nadu, India
}

\begin{abstract}
Several studies have revealed that certain naturally occurring medicinal plants inhibit the growth of various cancers. The present study was conducted to evaluate cytotoxicity and apoptotic induction potential of Myristica fragrans Houtt mace extract. The cytotoxic activity of the Myristica fragrans Houtt mace acetone extract was assayed by MTT assay on human oral epidermal carcinoma KB cell lines. KB cells were incubated with different concentration of mace extract ranging from 25 to $125 \mu \mathrm{g} / \mathrm{mL}$ for $24 \mathrm{hrs}$. The apoptotic induction potential was also studied by the analysis of $\mathrm{Bcl}-2$ protein and gene expression in mace extract incubated $\mathrm{KB}$ cell lines using western blotting technique and real-time polymerase chain reaction. The mace extract exhibited cytotoxicity and anticancer effect against KB cell lines and it also suppressed the growth of cancer cells, therefore growth inhibitory effect was noted in extract treated cell lines. The apoptotic potential of mace extract was accompanied by reduced gene expression of Bcl-2 compared to the untreated KB cells. The mace extract shows the cytotoxic activity and induced the apoptosis through the modulation of its target genes Bcl-2 in the KB cell lines, suggesting the potential of mace as a candidate for oral cancer chemoprevention. This can be further investigated in vivo for its anticancer potential.
\end{abstract}

Keywords: Myristica fragrans Houtt. (mace)/extract. Apoptosis. Cytotoxicity. KB cell lines. MTT assay. Bcl-2 gene.

\section{INTRODUCTION}

Oral cancer is one of the most common malignancies in the world. It is characterized by a high degree of local invasiveness and a high rate of metastasis to cervical lymph nodes. The migration of oral squamous cell carcinoma in to maxillary and mandibular bones is a common clinical problem(Sumitra, Nagani, 2013). The defective apoptosis (programmed cell death) which results in enhanced growth describes most cancer cells. Several proteins control the timing of the events in the cell cycle, which is tightly regulated to ensure that the cells divide only when necessary. The loss of this regulation is the hallmark of cancer (Rezafekrazad, Mehrad, Hamzeh, 2017). The increase in interest in apoptosis, or programmed cell

\footnotetext{
*Correspondence: M.Jainu. Department of Biochemistry, Biogen Care Research Centre, Chennai-600014, Tamil Nadu, India. E-mail: mallikajain@gmail.com
}

death has had a major impact on many fields with in the biological sciences, including Oncology. The delineation of discrete apoptotic pathway has affected not only our basic concepts of the development of cancer, but also our approaches towards the prevention and therapy of the disease (Maryam, Nadareh, Hossein, 2013). It is now evident that the balance between cellular proliferation and death plays a vital role in the maintenance of normal tissue homeostasis and the derangement of either of these processes can lead to the dysregulated clonal expansion that is characteristic of all neoplastic disease (Valter, Lombardi, Ramon, 2017).

Two different pathways, extrinsic and intrinsic, mainly play a role in the mechanisms of apoptosis. Also, in another pathway, the proteins $\mathrm{Bax}$ and $\mathrm{Bcl}-2$, which both belong to the Bcl-2 family, play adverse roles in apoptosis with their ratio being an important determinant of the susceptibility to apoptosis by regulating the proapoptotic and antiapoptotic proteins. Bcl-2 family proteins govern 
the mitochondrial outer membrane permeabilization (Ozgur et al., 2014; Thazin et al., 2017). Apoptosis results from a collapse of the cellular infrastructure through internal proteolytic digestion by some enzymes named caspases, leads to cytoskeletal disintegration, metabolic derangement and genomic fragmentation. The lack of effective diagnostic tool and the chemotherapeutics are the major constraints for controlling this type of cancer. Chemotherapy of oral cancer is largely ineffective and the clinical efficacy of the standard treatment with 5-fluorouracil (5-FU) is low. Furthermore, the resistance of oral cancer to chemotherapy and radiotherapy is a major problem (Jemal et al., 2011).

The natural products, especially plants have been used in the treatment of various diseases for thousands of years (Tajuddin et al., 2003). Mace is the aril part on the kernel of of Myristica fragrans Houtt (family: Myristicaceae), an evergreen aromatic tree cultivated in many tropical countries and is widely used as a spice and also to flavour many kinds of baked foods and vegetables (Kim et al., 2016). Myristica fragrans Houtt_exhibited a maximum number of plant constituents. The main constituents of Myristica fragrans Houtt have been found to be alkyl benzene derivatives (myristicin, elemicin, safrole, etc.), terpenes, alphapinene, beta-pinene, myristic acid, trimyristin, neolignan (myrislignan), and macelignan (Kim et al., 2016).

The chemical constituents of Myristica fragrans Houtt have been investigated by the scientists from various disciplines for hypolipidemic and hypocholesterolemic effects, antimicrobial, antidepressant, aphrodisiac, memory-enhancing, antioxidant, and hepatoprotective properties (Ulyana et al., 2016). Mace is widely used as a flavouring agent, a hair dye, and a folk medicine. It also possesses antipaillomagenic, anticarcinogenic, chemopreventive and anti-inflammatory activities (Kim et al., 2016; Jannu, Hussain, Rao, 1991). In dentistry application, mace lignan, an active compound from seed had strong anticarcinogenic activity and antibacterial effect (Ulyana et al., 2016). Since then there is no study that has been published to indicate the potential apoptotic activities of mace extract on oral carcinoma cell lines. Hence the aim of the study was to evaluate the cytotoxic and apoptotic potential of acetone mace extract on human oral epidermoid carcinoma KB cells.

\section{MATERIAL AND METHODS}

\section{Chemicals and their sources}

The authenticated sample of dried mace of Myristica fragrans Houtt was procured from the Herbal Care and Cure Centre (Chennai, India) and the sample was identified with the help of a botanist at the Central Drug Research Institute, Chennai before the study was carried out. All other chemicals used for this study were of analytical grade purchased from Sigma Aldrich Company, USA.

\section{Extraction}

The dried powder sample of mace $(80 \mathrm{~g})$ was extracted three times by hot percolation method with $1: 5$ ratio volume of acetone at room temperature for 72 hours. The filtrates were concentrated under reduced pressure at $40^{\circ} \mathrm{C}$ and stored at the room temperature for use in subsequent experiments (Gayathri, Anuradha, 2015).

\section{Cell lines}

KB cell lines were procured from the National Centre for Cell Sciences, Pune. The cells were maintained in Minimal Essential Medium enhanced with $10 \%$ FBS, streptomycin $(100 \mu \mathrm{g} / \mathrm{mL})$ and penicillin $(100 \mathrm{U} / \mathrm{mL})$, in a humidified atmosphere of $50 \mu \mathrm{g} / \mathrm{mL} \mathrm{CO}_{2}$ at $37^{\circ} \mathrm{C}$.

\section{Maintenance of cell lines}

The vial containing the $\mathrm{KB}$ cell lines acquired from ATCC (CCL - 17) was removed from liquid nitrogen freezer and immediately placed in a $37{ }^{\circ} \mathrm{C}$ water bath. It was agitated continuously until the medium thawed. Then it was centrifuged for $10 \mathrm{~min}$ at 150 to $200 \times \mathrm{g}$, room temperature. Supernatant was discarded and cells were washed with fresh medium to remove residual DMSO.

\section{MTT assay for cytotoxicity}

The MTT assay (Mossman, 1983) is based on the ability of live but not the dead cells to reduce a yellow tetrazolium dye to a purple formazan product. The cells were maintained in DMEM medium, supplemented with $10 \%$ Fetal Bovine Serum, at $37{ }^{\circ} \mathrm{C}$ in humidified atmosphere with $5 \% \mathrm{CO}_{2}$. The $\mathrm{KB}$ cells were plated in 96 well flat bottom tissue culture plates at a density of approximately $1.2 \mathrm{X} 10^{4}$ cells/well and allowed to attach overnight at $37^{\circ} \mathrm{C}$. The medium was then discarded and cells were incubated with the different concentrations of the samples $(25,50,75,100$ and $125 \mu \mathrm{g} / \mathrm{mL})$ for $24 \mathrm{~h}$. After the incubation, medium was discarded and $100 \mu \mathrm{L}$ fresh medium was added with $10 \mu \mathrm{L}$ of MTT $(5 \mathrm{mg} / \mathrm{mL})$. After $4 \mathrm{~h}$, the medium was discarded and $100 \mu \mathrm{L}$ of DMSO was added to dissolve the formazan crystals. Then, the absorbance was read at $570 \mathrm{~nm}$ in a microtitre plate reader. Cyclophosphamide was used as a positive control. 
The cell survival was calculated by the following formula:

$$
\begin{gathered}
\text { Viability } \%=(\text { Test OD/ Control OD) X } 100 \\
\text { Cytotoxicity } \%=100-\text { Viability } \%
\end{gathered}
$$

\section{Study of cellular morphology}

$\mathrm{KB}$ cells were seeded in 6 -well plates at $2 \times 10^{5}$ cells per well in $5 \mathrm{~mL}$ of complete growth medium, incubated with extract at concentrations $100 \mu \mathrm{g} / \mathrm{mL}$. The control cells treated with $0.1 \%$ DMSO alone were also included. The morphological changes were observed under a phase contrast light microscope after 24 hours and 48 hours. The images were captured at a magnification of x200.

\section{Annexin/PI Assay}

The cells $(2 \mathrm{~mL})$ at a density of $5 \times 10^{4}$ were grown in $40-\mathrm{mm}$ petri dishes and allowed to attach for $24 \mathrm{~h}$ after which cells were treated with the $100 \mu \mathrm{g} / \mathrm{mL}$ extract for $24 \mathrm{~h}$ and $48 \mathrm{~h}$. After the various treatment periods, cells were harvested and centrifuged at $335 \mathrm{~g}$ for $10 \mathrm{~min}$. The supernatants were washed in 1\% PBS and re-suspended in Annexin $\mathrm{V}$ binding buffer. The cells were centrifuged at $335 \mathrm{~g}$ for $10 \mathrm{~min}$ and the supernatants were discarded. The cell extracts were suspended in $100 \mu \mathrm{L}$ Annexin V binding buffer and $5 \mu \mathrm{L}$ Annexin V Alexa Fluor 488 was added and allowed to incubate in the dark for 15 minutes. PI $(4 \mu \mathrm{L})$ diluted in $1 \mathrm{x}$ Annexin V binding buffer $(1: 10)$ was added and allowed to incubate for 15 minutes in the dark at room temperature. Annexin V binding buffer $(500 \mu \mathrm{L})$ was added to wash the Annexin/PI stained cells. Annexin/PI was evaluated on a Becton Dickinson FACScan instrument fitted with a $488 \mathrm{~nm}$ argon laser. A minimum of 10,000 cells per sample were acquired and analyzed using CellQuest Pro software.

\section{Western blot analysis}

The cell pellet was dissolved in a $1 \%$ cell lysate buffer and centrifuged for $10 \mathrm{~min}$ at $12,000 \mathrm{rpm}$. The total cellular protein $(50 \mu \mathrm{g})$ was separated by using $10 \%$ sodium dodecyl sulfate-polyacrylamide gel electrophoresis (SDSPAGE) and transferred onto a polyvinylidene difluoride (PVDF) membrane. The membrane was then blocked with $5 \%$ calf serum albumin. Afterwards the membrane was incubated for 2 hours with primary mouse anti-human Bcl-2 monoclonal antibody. The membrane was then probed for 1 hour at room temperature with horseradish peroxidaselabelled secondary antibody. The signal was revealed using 3,3-diaminobenzidine tetrahydrochloride (DAB) as the HRP substrate. The Quantification of the western blots was determined by scanning the blots with Adobe Photoshop and performing densitometry with Bio-1D Image.

\section{Bcl-2 gene expression by RT-PCR}

The total RNA from cell lines were isolated using the ONE STEP-RNA Reagent (Biobasic Inc.). After the RNA isolation, the RNA was immediately reverse transcribed with Easy Script Plus ${ }^{\mathrm{TM}}$ Reverse Transcriptase. It was a novel recombinant reverse transcriptase that exhibits much higher efficiency in the synthesis of first strand cDNA from RNA templates. It has been engineered for RNA templates with complicated secondary structure and high GC contents. For RT PCR reaction, 1-2 $\mu \mathrm{g}$ of RNA was used corresponding to $1-10 \mu \mathrm{L}$ of the total RNA isolate.

\section{cDNA preparation}

RNA isolated from the fresh tissue samples was reverse transcribed where oligo-dT was used as a primer. Into a $1.5 \mathrm{~mL}$ Eppendorf PCR tube, $1-2 \mu \mathrm{g}$ of RNA (at least $1 \mu \mathrm{L}$ at most $10 \mu \mathrm{L}$ ), $2 \mu \mathrm{L}$ of oligo-dT (stock was $10 \mu \mathrm{M}$ ) was added and the total volume was completed up to $12.5 \mu \mathrm{L}$ with DEPC treated water. The tube was incubated at $65^{\circ} \mathrm{C}$ for $5 \mathrm{~min}$ (Water Bath) and chilled on ice. Then, $4 \mu \mathrm{L}$ of $5 \mathrm{X}$ reverse transcriptase buffer (final concentration $1 \mathrm{X}$ ), $2 \mu \mathrm{L}$ of $25 \mathrm{mM}$ dNTP mix (final concentration $2.5 \mathrm{mM}$ ), and $0.5 \mu \mathrm{L}$ of RNase inhibitor ( $40 \mathrm{U} / \mu \mathrm{L})$ were added in the indicated order. After incubating at $42^{\circ} \mathrm{C}$ for 5 minutes, $1 \mu \mathrm{L}$ of Easy Script reverse transcriptase $(200 \mathrm{U} / \mu \mathrm{L})$ was added. The reaction was carried out at $42^{\circ} \mathrm{C}$ for $50 \mathrm{~min}$. Finally, the tube was heated up to $70^{\circ} \mathrm{C}$ for $10 \mathrm{~min}$ and chilled on ice. The samples were stored at $-20^{\circ} \mathrm{C}$ until further use.

\section{The polymerase chain reaction (PCR)}

The cDNA obtained was amplified by PCR (Chomczynski, Sacchi, 1987). The Gene Specific PCR was used to amplify $\mathrm{BCl}_{2}$ gene. A constitutively expressed gene, namely GAPDH, was chosen in order to assess the quality of PCR (Table I).

The primer sequences used for the PCR amplification

\begin{tabular}{|c|c|c|}
\hline Genes & Primer right & Primer left \\
\hline $\mathrm{BCl}_{2}$ & 5'-GGATTCATGACCAGGGAGTTC-3' & 5'-GCGGTCTCCACTGAGAATAAT-3' \\
\hline GAPDH & 5'-GGCCAACCGTGAAAAGATG-3' & 5'-GGATCTTCATGAGGTAGTCTC-3' \\
\hline
\end{tabular}
were as follows: 


\section{Statistical analysis}

The data are given as the mean \pm standard deviation (SD). The statistical analysis was performed by using one-way analysis of variance (ANOVA), followed by a Dunnett's multiple-comparison test with $95 \%$ confidence intervals. A P-value $<0.01$ was considered to indicate a statistically significant difference.

\section{RESULTS}

The effect of anticancer from mace extract on $\mathrm{KB}$ cell lines was evaluated through the micro-culture tetrazolium assay (MTT). The multiple concentrations from the mace extract were used and the effective doses were calculated from the dose-response curve. The results of the cytotoxicity evaluation against $\mathrm{KB}$ cell line of the mace extract are shown in Figure 1. From the above figures, we can easily determine the percentage of cell viability for five different concentration of 25,50 , 75,100 and $125 \mu \mathrm{g} / \mathrm{mL}$ mace extract. The shape of the curve shows significant inhibition of cell proliferation in $\mathrm{KB}$ cell line (Figure 2) in a dose-dependent manner after 24 hours of treatment. The cell viability of mace extract was $41.40,46.99,51.52,55.61$ and $58.51 \%$ respectively as shown in (Figure 1). Hence, the half maximal inhibitory concentration of mace extract was at the concentration of $75 \mu \mathrm{g} / \mathrm{mL}$ (Figure 2).

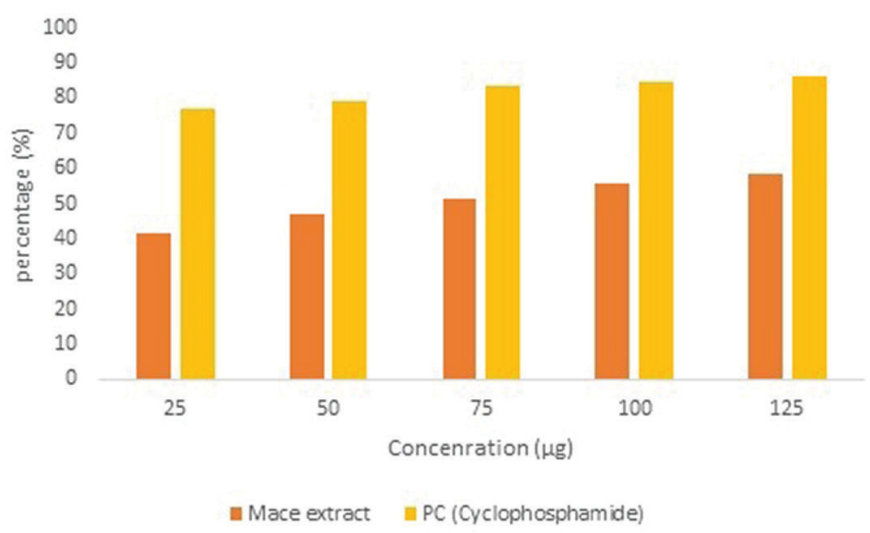

FIGURE 1 - Effect of mace extract and positive control cyclophosphamide cytotoxicity action on KB cells, 24h after exposure. The effect was measured by MTT cell viability assay. The data are mean $\pm \mathrm{SD}$ of three independent experiments.

After 48 hours of treatment, the higher concentrations $(100 \mu \mathrm{g} / \mathrm{mL})$ killed more than $50 \%$ of cells. The apoptosisinducing potential of the extract was further tested in the cancer cells using the Annexin-FITC/propidium iodide double staining flow cytometric assay (Table I). The

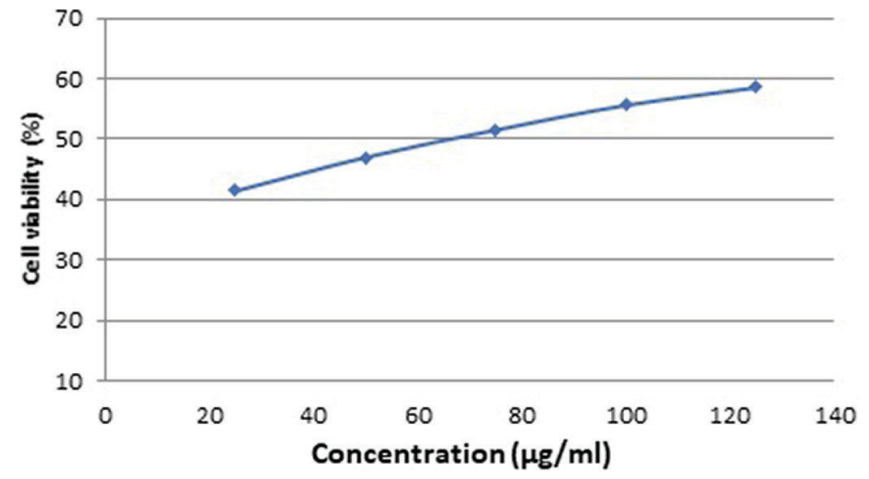

FIGURE 2 - Effects of $\mathrm{IC}_{50}$ concentration of acetone extract of mace extract.

decrease in the cell population was seen with the increase in the extract incubation. As can be seen in Figure 3, the cells with $100 \mu \mathrm{g} / \mathrm{mL}$ doses of extract revealed cellular shrinkage and overall morphological alterations.

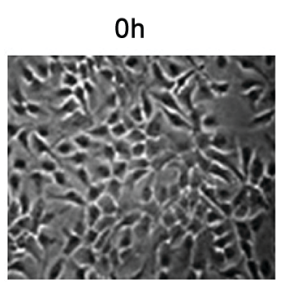

Control

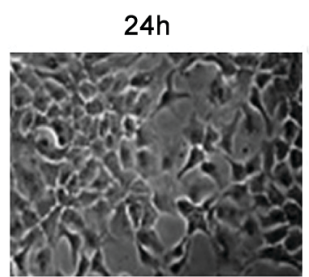

$100 \mu \mathrm{g} / \mathrm{mL}$

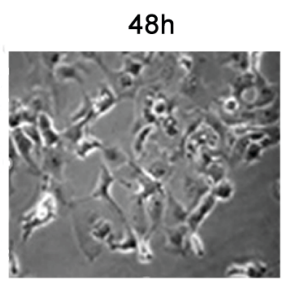

$100 \mu \mathrm{g} / \mathrm{mL}$
FIGURE 3 - The effect of Mace extract on morphology of KB cells. Cells were treated with vehicle (DMSO) or various doses of mace acetone extract ( $100 \mu \mathrm{g} / \mathrm{mL}$ for KB cells) for $24 \mathrm{~h}$ and $48 \mathrm{~h}$. Cell viability was determined by photographs captured by phase contrast microscope at magnification, $\times 200$.

TABLE I - The percentage of cell population in different stages (live, apoptotic and necrotic) following the extract treatment and evaluated by double staining I Annexin V-FITC/PI using flow cytometric assay

\begin{tabular}{lcc}
\hline & $\mathbf{2 4} \mathbf{h}$ & $\mathbf{4 8} \mathbf{~ h}$ \\
\hline Live (\%) & 72.15 & 20.16 \\
Early apoptosis (\%) & 33.17 & 30.45 \\
Late apoptosis (\%) & 20.54 & 40.12 \\
Dead (\%) & 0.12 & 51.36 \\
\hline
\end{tabular}

As observed in the Figure 4 and 5, Bcl-2 protein expression reduced after treatment with the mace extract. This advocates a key role for the mitochondria in mace extract -induced apoptosis. Levels of Bcl-2 genes expression in KB cells treated with acetone extract results are represented in Figure 6. The Bcl-2 gene expression was found to be decreased in the extract treated cells in 
comparison to the untreated cells, whereas GAPDH gene expression remained the same in both sample treated and untreated cells. The quantitative measurements of Bcl-2 expression was done and it is shown in the Figure 7.

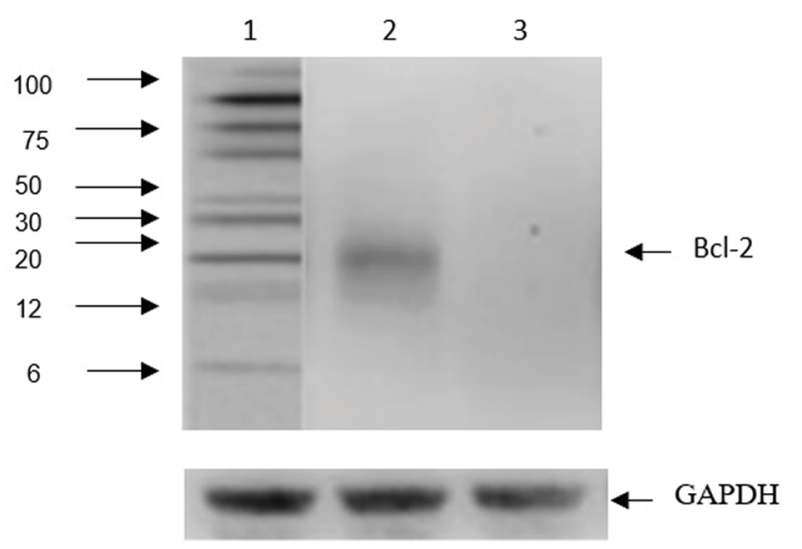

FIGURE 4 - Effect of mace extract treatment on Bcl-2 protein expression in KB cells. Lane 1 -Marker Lane; Lane 2- Bcl-2 protein expression in control $\mathrm{KB}$ cells; Lane $3-\mathrm{Bcl}-2$ protein expression in extract treated KB cells.

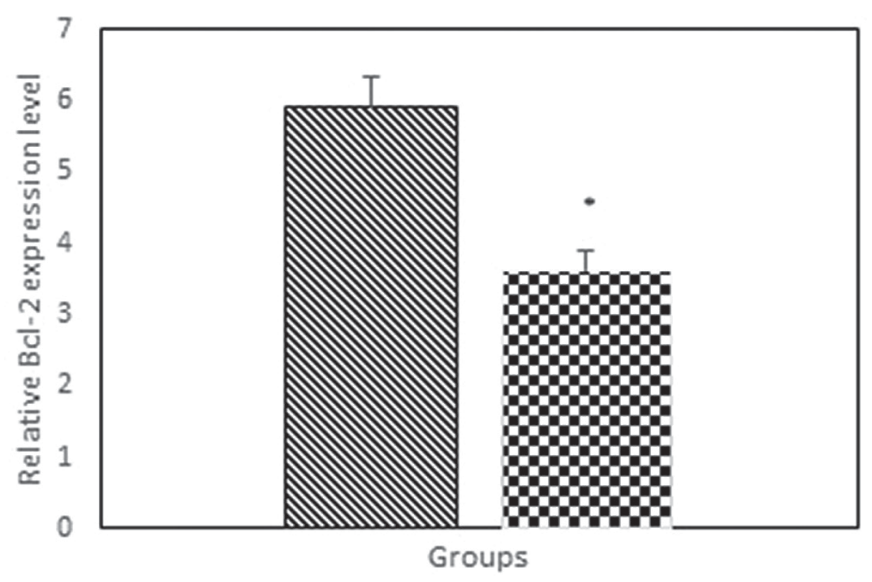

$\mathbf{Q B}$ cells positive control axtract treated KB cells

FIGURE 5 - Relative intensity of Bcl-2 protein levels were expressed as means in bar graphs. Significant differences from positive control were noted as ${ }^{*} \mathrm{P}<0.01$.

\section{DISCUSSION}

The discovery and development of chemotherapeutics that are effective for the treatment and control of oral cancer is urgently needed. The natural products are still important sources to discover new anticancer drugs. Several studies have revealed that certain naturally occurring medicinal plants inhibit the growth of various cancers (Eun-Sun et al., 2012). The methanol extract of the bark of $M$. fragrans Houtt

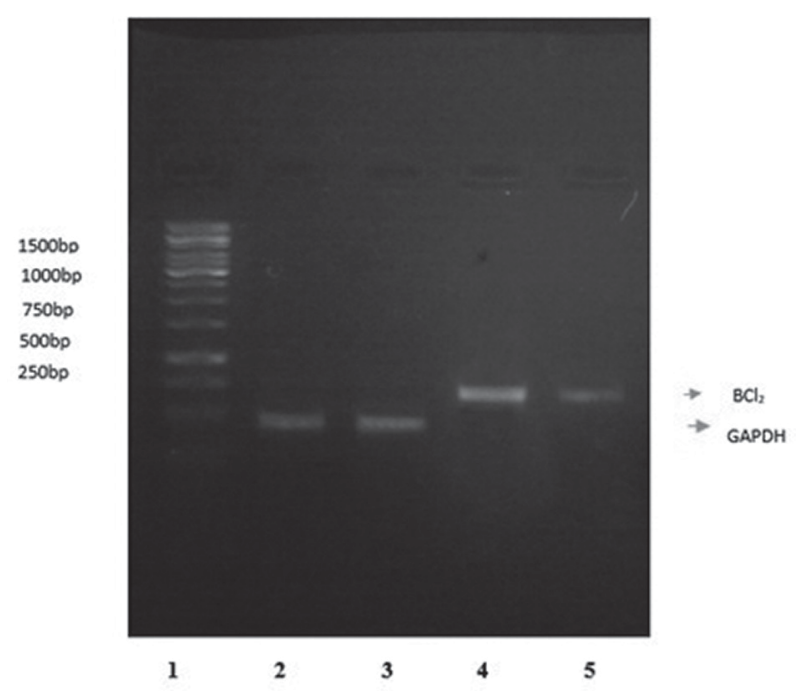

FIGURE 6 - Effect of mace extract treatment on $\mathrm{BCl}_{2}$ gene expression in KB cells. Lane 1 - 1 1KB DNA Ladder; Lane 2 - GAPDH expression in control KB cells; Lane 3 - GAPDH expression in mace extract treated $\mathrm{KB}$ cells; Lane $4-\mathrm{BCl}_{2}$ gene expression in control $\mathrm{KB}$ cells; Lane $5-\mathrm{BCl}_{2}$ gene expression in extract treated $\mathrm{KB}$.

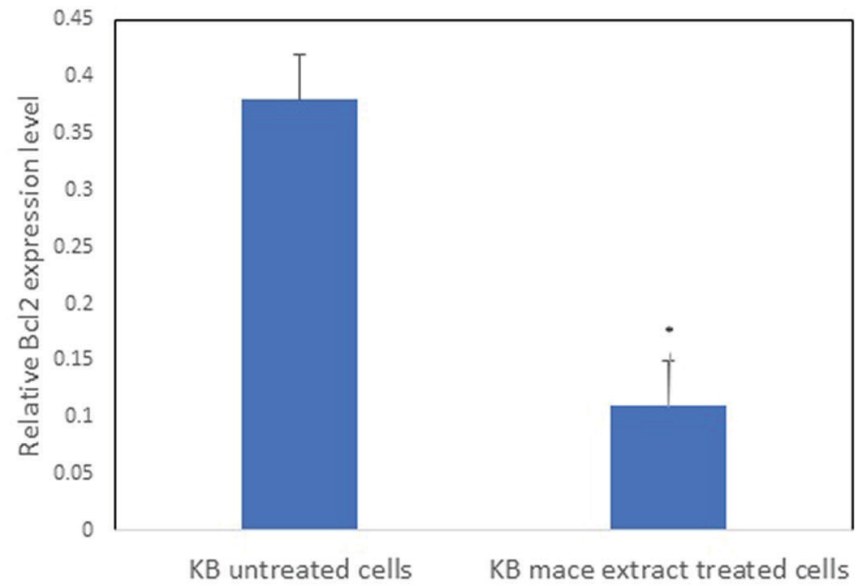

FIGURE 7 - The m-RNA expression levels were analyzed by densitometry, and the data is presented as mean intensity in relative arbitrary densitometric units (ADU) $\pm \mathrm{SEM}$ with $\mathrm{n}=3$. ${ }^{*} \mathrm{P}<0.01$ are statistically significant compared to KB untreated cells.

inhibited jurkat T Leukemia cell line proliferation through apoptosis induction and induced SIRT1m RNA down regulation (Chirathaworn et al., 2007).

The mace extract was screened for its cytotoxicity against $\mathrm{KB}$ cell lines at different concentrations to determine the $\mathrm{IC}_{50}(50 \%$ growth inhibition $)$ by MTT assay. The exposure of KB cell lines with varying concentration of mace extract resulted in a concentration dependent inhibition of cell proliferation, suggesting that the acetone 
mace extract inhibited the proliferation of KB cells, cyclophosphamide was used as a positive control.

The Annexin/PI assay also confirmed the ability of the extract to induce early and late apoptosis. Cancer cells, however, exhibit resistance to apoptosis in order to sustain their uncontrolled proliferation and, therefore, any apoptosis modulating compound is desirable as a plausible chemotherapeutic agent against cancer. KB cells were treated with $100 \mu \mathrm{g} / \mathrm{mL}$ concentration of mace extract for 24 and 48 hours. The extract induced both early and late apoptosis as compared to the untreated control.

The mitotic inhibitory effect of $M$. fragrans Houtt. was cytotoxic because this activity of the extract was induced in a concentration-dependent manner. Our results are in accordance with the previous report on the cytotoxic activity of M. fragrans Houtt. (Chirathaworn et al., 2007). Lignans, which are important class of plant-derived compounds, possess a variety of biological activities such as antitumor, antimitotic, antiviral and antiatherosclerotic activities. The antitumor activity of lignans can also justify the observed cytotoxic effect of $M$. fragrans Houtt. (Essam, Aseel, Massody, 2012). The previous results suggest mitodepressive and antimutagenic potentials of water extract of the leaves of $M$. fragrans Houtt. as desirable properties of a promising anticancer agent (Akeem et al., 2011). Some constituents present in mace extract possess potent antioxidant and anti-inflammatory activities and some of them exhibit cancer preventive activity in experimental carcinogenesis (Plengsuriyakarn et al., 2012). These previous findings support the current study.

The Bcl-2 oncoprotein suppresses or delays the induction of apoptosis in prostate, skin, lymphoid tissues, and mammary gland. The apoptotic pathway includes the extrinsic (cytoplasmic) and intrinsic (mitochondrial) pathways. Permeabilization of the mitochondrial outer membrane is importantly associated with Bcl2 family proteins that regulate the integrity of the mitochondria (In-Hyoung et al., 2015).

The acetone mace extract treated and cultured cells were harvested and further analysed for the expression of $\mathrm{BCl}_{2}$ gene, and the results showed a decrease in the expression. This is in agreement with the previously reported potential antitumour activity of the mace extract (Datta, Kojima, Yoshida, 1997). Thus, acetone mace extract exerts its antitumour role by lowering the expression of $\mathrm{BCl}_{2}$ gene in $\mathrm{KB}$ cells, which points to the mechanism of action related to activation of apoptosis. The activities of this plant may be due to the presence of mace lignans compound. Their biological effects include antibacterial, anti-thrombotic and vasodilatory, antimutagenic, lipoxygenase and cycloxygenase inhibition scavenging of reactive oxygen species, and antitumourigenic (Essam, Aseel, Massody, 2012). In conclusion, the results of the present study suggest that the acetone mace extract may contain bioactive compound myristicin, that induces apoptosis of KB cells. The additional studies are required to characterize the bioactive compounds responsible for the observed activities of mace plant as a novel resource for new anticancer drugs.

\section{CONCLUSION}

In conclusion, the mace extract functions as a broad-spectrum anticancer agent in human cancer cells by blocking cell cycle and further triggering apoptosis via the intrinsic pathway. In addition, the mace extract has less cytotoxic effect on normal cells, and is selective at inducing apoptosis between cancer and normal cells. Therefore, mace is a potential candidate, as a powerful chemotherapeutic agent.

\section{CONFLICTS OF INTEREST STATEMENT}

There is no conflict of interest.

\section{REFERENCES}

Akeem A, Kamaruzaman BM, Mohd Zaini A, Shaida Fariza S, Othman Ahmad S. Antioxidants in aqueous extract of Myristica fragrans (Houtt.) suppress mitosis and cyclophosphamideinduced chromosomal aberrations in Allium cepa L. cells. J Zhejiang Univ Sci B. 2011;12(11):915-922.

Chirathaworn C, Kongcharoensuntorn W, Dechdoungchan T, Alisa Lowanitchapat PS, Poovorawan Y. Myristica fragrans Houtt. methanolic extract induces apoptosis in a human leukemia cell line through SIRT1 mRNA downregulation. J Med Assoc Thai. 2007;90(11):2422-2428.

Chomczynski P, Sacchi N. Single step method of RNA isolation by acid guanidinium thiocyanate-phenol-chloroform extraction. Anal Biochem. 1987;162(1):156-159.

Datta R, Kojima H. Yoshida K. Caspase 3-mediated cleavage of protein kinase $\mathrm{C}$ theta in induction of apoptosis. J Biol Chem. 1997;272(7):20317-20320.

Essam A, Aseel J, Massody A. Cytogenetic study of the pure Myristicin from Nutmeg (Myristica fragrans) on Rhabomyosarrcoma cell line (invitro). DAV International J Sci. 2012;1(2):161-164. 
Eun-Sun C, Jun-Sung K, Ki-Han K, Hyng-Seop K, Cho NP, Cho S. Methanol extract of Sanguisorba officinalis L. with cytotoxic activity against PC53 human prostate cancer cells. Mol Med Rep. 2012;6:670-674.

Gayathri R, Anuradha V. Phytochemical screening and total phenolic content of aqueous and acetone extracts of seed, butter, mace of Nutmeg (Myristica fragrans Houtt). International J Pharm Sci Rev Res. 2015;33(1):236-239.

In-Hyoung Y, Lee-Han K, Ji-Ae S, Sung-Dae C. Chemotherapeutic effects of Withaferin A in Human oral cancer cells. J Cancer Therapy. 2015;6(3):735-742.

Jannu LN, Hussain SP, Rao AR. Chemopreventive action of mace (Myristica fragrans, Houtt) on DMBA-induced papillomagenesis in the skin of mice. Cancer Lett. 1991;56(1):59-63.

Jemal A, Bray F, Center MM, Ferlay J, Ward E, Forman D. Global cancer statistics. Cancer J Clin. 2011;61(2):69-90.

Kim EY, Choi HJ, Park MJ, Jung YS. Myristica fragrans suppresses tumor growth and metabolism by inhibiting lactate dehydrogenase. Am J Chin Med. 2016;44(5):1063-79.

Maryam B, Nadereh R, Hossein N. Investigating apoptotic effects of methanolic extract of Doremaglabrum seed on WEHI164 cells. Pharmacology. 2013;3(2):48-54.

Mossman T. Rapid colorimetric assay for cellular growth and survival - Application to proliferation and cytotoxicity assays. J Immunol Methods 1983;65(1):55-63.

Ozgur C, Murat P, Elif C, Bilgin C, Kerem F. Evaluation of biological activities of Physalis Peruviana ethanol extracts and expression of $\mathrm{BCL}_{2}$ genes in Hela cells. Food Sci Tech. 2014;34(2):422-430.
Plengsuriyakarn T, Vithoon V, Veerachai E, Porntipa P, Piengchai K, Arunporn I, Kesara N. Anticancer activities against cholangiocarcinoma, toxicity and pharmacological activities of Thai medicinal plants in animal models. BMC Complement Altern Med. 2012;12(1):2-29.

Rezafekrazad A, Mehrad A, Hamzeh PA. Cytotoxic effect of Thymus Caramanicus Jalas on human oral epidermoid carcinoma KB cells. Braz Den J. 2017;28(1):72-77.

Sumitra C, Nagani K. Invitro and Invivo methods for Anticancer activity evaluation and some Indian medicinal plants possesing Anticancer properties: An overview. J Pharmacog Phytochem. 2013;2(2):140-152.

Tajuddin S, Shamshad A, Abdul L, Iqbal AQ. Aphrodisiac activity of 50\% ethanolic extracts of Myristica fragrans Houtt. and Syzygium aromaticum (L) Merr. \& Perry. (clove) in male mice: a comparative study. BMC Complement Altern Med. 2003;3(6):6-10.

Thazin N, Zhipeng Q, Daniel K, David L. Understanding the effectiveness of natural compounds mixtures in cancer through their molecular mode of action. Int J Mol Sci. 2017;18(3):656661.

Ulyana M A, Peter J, Blanco C, Susan M, Esperanza JC. New acyclic bis phenylpropanoid and neolignans, from Myristica fragrans Houtt., exhibiting PARP-1 and NF- $\mathrm{kB}$ inhibitory effects. Food Chem. 2016;202(1):269-275.

Valter RM, Lombardi I, Ramon C. Invitro screening for cytotoxic activity of herbal extracts. Evi Based Comp Alter Med. 2017;3(1):631-639.

Received for publication on $14^{\text {th }}$ January 2018 Accepted for publication on $23^{\text {rd }}$ January 2018 